\title{
Glycerol 3-phosphate dehydrogenase of boar spermatozoa: inhibition by $\alpha$-bromohydrin phosphate
}

\author{
A. R. Jones and L. Gillan \\ Department of Biochemistry, University of Sydney, Sydney NSW 2006, Australia
}

\begin{abstract}
Boar spermatozoa incubated with glycerol 3-phosphate as substrate produced $\mathrm{CO}_{2}$ and an accumulation of dihydroxyacetone phosphate and fructose-1,6-bisphosphate. The rate of oxidation of glycerol 3-phosphate was decreased, as was the production of $\mathrm{CO}_{2}$ and the two glycolytic intermediates, in the presence of $(R, S)$ - $\alpha$-bromohydrin phosphate. In the presence of inhibitors of stage two of the glycolytic pathway, $\mathrm{CO}_{2}$ production was prevented, there was a marked increase in the concentration of the glycolytic intermediates but the rate of metabolism of the substrate was unaffected. Oxygen consumption by spermatozoa incubated with glycerol 3-phosphate was unaffected in the presence of rotenone, whereas it was decreased when lactate was offered as the substrate. The results reported here confirm that in boar spermatozoa glycerol 3-phosphate dehydrogenase is an FAD-linked enzyme that is inhibited by $(R, S)$ - $\alpha$-bromohydrin phosphate in, possibly, a competitive manner.
\end{abstract}

\section{Introduction}

The male antifertility agent (S)- $\alpha$-chlorohydrin (3chloropropan-1,2-diol: I in Fig. 1) is oxidized within the spermatozoa of susceptible species to (S)-3-chlorolactaldehyde (II in Fig. 1) which inhibits the activities of triosephosphate isomerase and glyceraldehyde 3-phosphate dehydrogenase, thereby preventing the cells from synthesizing ATP which is essential for the maintenance of motility (Cooney and Jones, 1988 ). Early biochemical studies with the racemate, $(R, S)-\alpha$ chlorohydrin, led to the proposal that the active metabolite was the phosphorylated derivative, $\alpha$-chlorohydrin-1-phosphate (III in Fig. 1), although this was not supported by experimental evidence (Mohri et al., 1975). During the course of our investigations into the metabolic activity of boar spermatozoa, we have examined the possible effects of $(R, S)$ - $\alpha$-chlorohydrin1-phosphate and, while confirming that the compound had no action on the metabolism of fructose, glycerol or lactate (Jones and Chantrill, 1989), observed that it did inhibit the oxidation of glycerol 3-phosphate.

This apparent anomaly, the inhibition of the oxidation of glycerol 3-phosphate without affecting the metabolism of glycerol, was partially explained when it was shown that glycerol was metabolized, not by its conversion to glycerol 3-phosphate, but as glycerol $\rightarrow$ glyceraldehyde $\rightarrow$ glyceraldehyde 3-phosphate (Jones et al., 1992). Attempts to study the action of $(R, S)$ - $\alpha$-chlorohydrin-1-phosphate on the metabolism of glycerol 3-phosphate were hindered by the presence of wide-range phosphatase activity in the samples of boar spermatozoa being used which converted (S)- $\alpha$ chlorohydrin-I-phosphate to (S)- $\boldsymbol{\alpha}$-chlorohydrin, thereby allowing the formation of (S)-3-chlorolactaldehyde (Porter and

Received 7 February 1996.
Jones, 1995). To overcome this, we have synthesized $(R, S)-\alpha$ bromohydrin-1-phosphate and confirmed that this compound also inhibited the metabolism of glycerol 3-phosphate without affecting that of any other substrate since its hydrolysis, to $(R, S)-\alpha$-bromohydrin, produces a compound that has no action on spermatozoa either in vivo (Banik et al., 1972) or in vitro (Jones and Porter, 1995). The use of 3-chloro-1hydroxypropanone (Jones et al., 1986) and 3-bromopyruvate (Jones et al., 1995), which are specific inhibitors of stage two of the glycolytic pathway in boar spermatozoa, has enabled us to determine that $(R, S)-\alpha$-bromohydrin-1-phosphate inhibits glycerol 3-phosphate dehydrogenase in what appears to be a competitive manner and that the enzyme is FAD-linked and probably bound to the mitochondrial membrane.

\section{Materials and Methods}

Substrates and chemicals

L- $\left[\mathrm{U}-{ }^{14} \mathrm{C}\right] \mathrm{Glycerol}$ 3-phosphate, $\left.{ }^{14} \mathrm{C}\right]$ fructose and $\mathrm{L}-\left[\mathrm{U}-{ }^{14} \mathrm{C}\right]$ lactate were purchased from

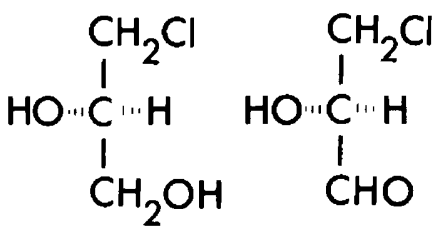

1
II

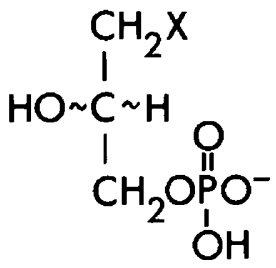

III
Fig. 1. The structures of (S)- $\alpha$-chlorohydrin (I), (S)-3chlorolactaldehyde (II), (R,S)- $\alpha$-chlorohydrin phosphate (III, $\mathrm{X}=\mathrm{Cl}$ ) and $(R, S)$ - $\alpha$-bromohydrin phosphate (III, $X=\mathrm{Br}$ ). 
Amersham International plc (Amersham, Bucks). All enzymes, substrates and co-factors were obtained either from Sigma Chemical Co. (St Louis, MO) or Boehringer Mannheim Australia Pty Ltd (Castle Hill, NSW). All other chemicals and reagents were of analytical grade and all solutions were prepared in water purified by reverse osmosis.

3-Chloro-1-hydroxypropanone was prepared from 3-chloro1-hydroxypropanone dimethyl acetal by the procedure of Jones et al. (1986). Neutralized solutions of chlorohydroxypropanone $\left(10 \mathrm{mmol} \mathrm{l}^{-1}\right)$ were prepared immediately before use and added to incubations at a final concentration of $0.5 \mathrm{mmol} \mathrm{I}^{-1}$. $(R, S)$ - $\alpha$-Bromohydrin phosphate biscyclohexylamine salt was synthesized by the method of Mashford and Jones (1978); recrystallization from dioxane gave the compound as white crystals, m.p. $148-150^{\circ} \mathrm{C}$ (reported m.p. (Fondy et al., 1970) $124-127^{\circ} \mathrm{C}$ ). 3-Bromopyruvate hydrate, purchased from Aldrich Chemical Co. (Milwaukee, WI), was recrystallized several times from dry chloroform, m.p. $74-77^{\circ} \mathrm{C}$ (reported m.p. (Sprinson and Chargaff, 1946) $74^{\circ} \mathrm{C}$ ). Solutions were neutralized with solid $\mathrm{NaHCO}_{3}$ and the compound added to incubates as sodium bromopyruvate at a final concentration of $0.5 \mathrm{mmol} \mathrm{l}^{-\mathrm{I}}$.

\section{Metabolic studies}

Cauda epididymides, excized from the testis-epididymis complex of mature boars (Sus scrofa; various crosses of Duroc, Hampshire, Landrace and Large White) 15-20 min after slaughter at the abattoir, were placed immediately in Dewar flasks containing PBS (Stevenson and jones, 1985) at $34^{\circ} \mathrm{C}$. The sealed flasks were transported to the laboratory where the spermatozoa were flushed from the epididymides with PBS $\left(34^{\circ} \mathrm{C}\right)$ from incisions made in the third and fourth segments of the cauda according to the classification of Holtz and Smidt (1976). The spermatozoa were washed and prepared as a $10 \%$ $(\mathrm{v} / \mathrm{v})$ suspension in PBS at $34^{\circ} \mathrm{C}$ according to our established procedure (Jones and Chantrill, 1989). Each suspension, containing spermatozoa from $10-15$ boars, contained $15-20 \mathrm{mg}$ protein $\mathrm{ml}^{-1}$ representing of the order of $10^{7} \mathrm{cells}^{-1}$.

Incubations were performed in standard Warburg flasks shaken at 120 oscillations min $^{-1}$ at $34^{\circ} \mathrm{C}$ with air as the gas phase. Incubations ( $1 \mathrm{ml})$ comprised substrate $(50 \mu \mathrm{l}, 200 \mathrm{nCi}$ if radioactive), inhibitor or PBS $(50 \mu \mathrm{l})$ and were started with the addition of the $10 \%$ sperm suspension $(900 \mu \mathrm{l})$. Incubations were terminated by the addition of $3 \mathrm{~mol} \mathrm{HClO}_{4} \mathrm{l}^{-1}(100 \mu \mathrm{l})$ and the deproteinized, neutralized and desalted incubation solutions used for the assays of substrates and products. Time-course incubations were performed in open $25 \mathrm{ml}$ conical flasks and aliquots $(1 \mathrm{ml})$ were taken at specified periods and added to $3 \mathrm{~mol} \mathrm{HClO}_{4} \mathrm{I}^{-1}(100 \mu \mathrm{l})$. Zero-time samples were removed approximately $10-15 \mathrm{~s}$ after preparation of the incubation suspensions. Assays for metabolically derived $\mathrm{CO}_{2}$ (Stevenson and Jones, 1982), fructose-1,6-bisphosphate and dihydroxyacetone phosphate (Michal and Beutler, 1975), glycerol 3-phosphate and lactate (Lang, 1985) were performed according to the literature. Protein was estimated (Lowry et al., 1951) using BSA as a standard.

Suspensions of spermatozoa $(10 \% \mathrm{v} / \mathrm{v}, 10 \mathrm{ml})$ were centrifuged at $2000 \mathrm{~g}$ for $5 \mathrm{~min}$ at $4{ }^{\circ} \mathrm{C}$. The supernatant solutions were discarded; the pellets suspended in sucrose $\left(0.25 \mathrm{mmol} \mathrm{l}^{-1}, 1.25 \mathrm{ml}\right)$ containing $\operatorname{EDTA}\left(1 \mathrm{mmol} \mathrm{l} \mathrm{l}^{-1}\right)$ and mercaptoethanol ( $1 \mathrm{mmol} \mathrm{l^{-1 }}$ ); and the cells disrupted by shaking with Triton $\mathrm{X}-100(1 \%, 0.14 \mathrm{ml})$. The suspensions were centrifuged at $20000 \mathrm{~g}$ for $10 \mathrm{~min}$ at $4^{\circ} \mathrm{C}$ and the supernatant solutions assayed for $\mathrm{NAD}^{+}$-dependent glycerol 3-phosphate dehydrogenase activity (Lang, 1985).

The oxygen consumption of sperm suspensions was measured using an oxygen electrode (Model 10, Rank Bros, Cambridge) calibrated with air-saturated water $(240 \mu \mathrm{mol}$ $\mathrm{O}_{2} \mathrm{l}^{-1}$ at $34^{\circ} \mathrm{C}$ ) (Umbreit et al., 1957). Sperm suspensions (5\% $(\mathrm{v} / \mathrm{v}), 900 \mu \mathrm{l})$ were placed in the reaction chamber and vigorously stirred at $34^{\circ} \mathrm{C}$. Substrates and inhibitors $(50 \mu l)$ were added at final concentrations of $0.5 \mathrm{mmol} \mathrm{l}^{-1}$ (fructose), $1 \mathrm{mmol} \mathrm{l} \mathrm{l}^{-1}$ (glycerol 3-phosphate and lactate), $700 \mu \mathrm{mol} \mathrm{l}^{-1}$ (rotenone), $0.25 \mathrm{mmol} \quad \mathrm{1}^{-1} \quad$ (3-bromopyruvate and a-bromohydrin phosphate).

Preliminary inhibition studies were performed by incubating sperm suspensions for $20 \mathrm{~min}$ in the presence of $\alpha$-bromohydrin phosphate $\left(0,5\right.$ and $\left.10 \mathrm{mmol} \mathrm{l}^{-1}\right)$ and a range of concentrations of L-glycerol 3-phosphate (1-10 $\mathrm{mmol} \mathrm{l}^{-1}$ ). The fall in the concentration of glycerol 3-phosphate over this period was equated to the velocity of the reaction.

\section{Statistical analyses}

Values are presented as the mean $\pm \operatorname{SEM}$ for the number $(n)$ of experiments performed. Significance of difference was determined by an unpaired two-tailed $t$ test.

\section{Results}

Boar spermatozoa oxidatively metabolized fructose, glycerol, glycerol 3-phosphate and lactate to $\mathrm{CO}_{2}$, but dihydroxyacetone phosphate and fructose-1,6-bisphosphate accumulated only from glycerol 3-phosphate and this was accompanied by comparatively less production of $\mathrm{CO}_{2}$ (Table 1 ). The production of $\mathrm{CO}_{2}$ from fructose, glycerol and lactate was unaffected by the presence of $\alpha$-bromohydrin phosphate $\left(5 \mathrm{mmol} \mathrm{I}^{-1}\right.$ ), but that from glycerol 3-phosphate was inhibited, the rate of metabolism of the substrate decreased (Fig. 2), and the concentrations of dihydroxyacetone phosphate and fructose-1,6bisphosphate were concomitantly lower (Fig. 3).

In the presence of 3-chloro-1-hydroxypropanone $(0.5 \mathrm{mmol}$ $\left.\mathrm{l}^{-1}\right)$ or 3-bromopyruvate $\left(0.5 \mathrm{mmol} \mathrm{1}^{-1}\right)$, the oxidation of glycerol 3-phosphate to $\mathrm{CO}_{2}$ was almost completely inhibited but neither compound had any appreciable effect on its rate of disappearance (Fig. 4). Unlike the effect of $\alpha$-bromohydrin phosphate, both chlorohydroxypropanone and 3bromopyruvate resulted in an increase in the concentrations of dihydroxyacetone phosphate and fructose-1,6-bisphosphate (Fig. 5).

The maximum $\mathrm{NAD}^{+}$-dependent glycerol 3-phosphate dehydrogenase activity in boar spermatozoa was determined to be such that it was able to convert approximately 700 pmoles of glycerol 3-phosphate to dihydroxyacetone phosphate $\min ^{-1} \mathrm{mg}^{-1}$ protein $(n=6)$. Thus, operating at maximum activity for $30 \mathrm{~min}$, approximately 20 nmoles of substrate could theoretically be oxidized in incubation 
Table 1. The production of $\mathrm{CO}_{2}$, dihydroxyacetone phosphate, fructose-1,6-bisphosphate and lactate by boar spermatozoa incubated at $34^{\circ} \mathrm{C}$ for $1 \mathrm{~h}$ with different substrates

\begin{tabular}{|c|c|c|c|c|c|}
\hline Substrate & $n$ & $\mathrm{CO}_{2}$ & $\begin{array}{c}\text { Dihydroxyacetone } \\
\text { phosphate }\end{array}$ & $\begin{array}{l}\text { Fructose-1,6- } \\
\text { bisphosphate }\end{array}$ & Lactate \\
\hline Glycerol 3-phosphate (2 $\left.\mathrm{mmol} \mathrm{l}^{-1}\right)$ & 13 & $30.0 \pm 1.7$ & $21.0 \pm 2.1$ & $7.8 \pm 0.8$ & $25.0 \pm 2.4$ \\
\hline Fructose $\left(1 \mathrm{mmol} \mathrm{l}{ }^{-1}\right)$ & 8 & $75.0 \pm 8.9$ & $0.4 \pm 0.1$ & $0.1 \pm 0.1$ & $44.2 \pm 5.8$ \\
\hline Glycerol (2 mmol 1-1) & 7 & $62.1 \pm 11.2$ & $1.0 \pm 0.2$ & $0.3 \pm 0.1$ & $51.1 \pm 5.7$ \\
\hline Lactate $\left(2 \mathrm{mmol} \mathrm{l}^{-1}\right)$ & 4 & $110 \pm 1$ & $0.3 \pm 0.1$ & 0 & $50.1 \pm 6.3$ \\
\hline
\end{tabular}

Values are nmoles per $\mathrm{mg}$ protein.
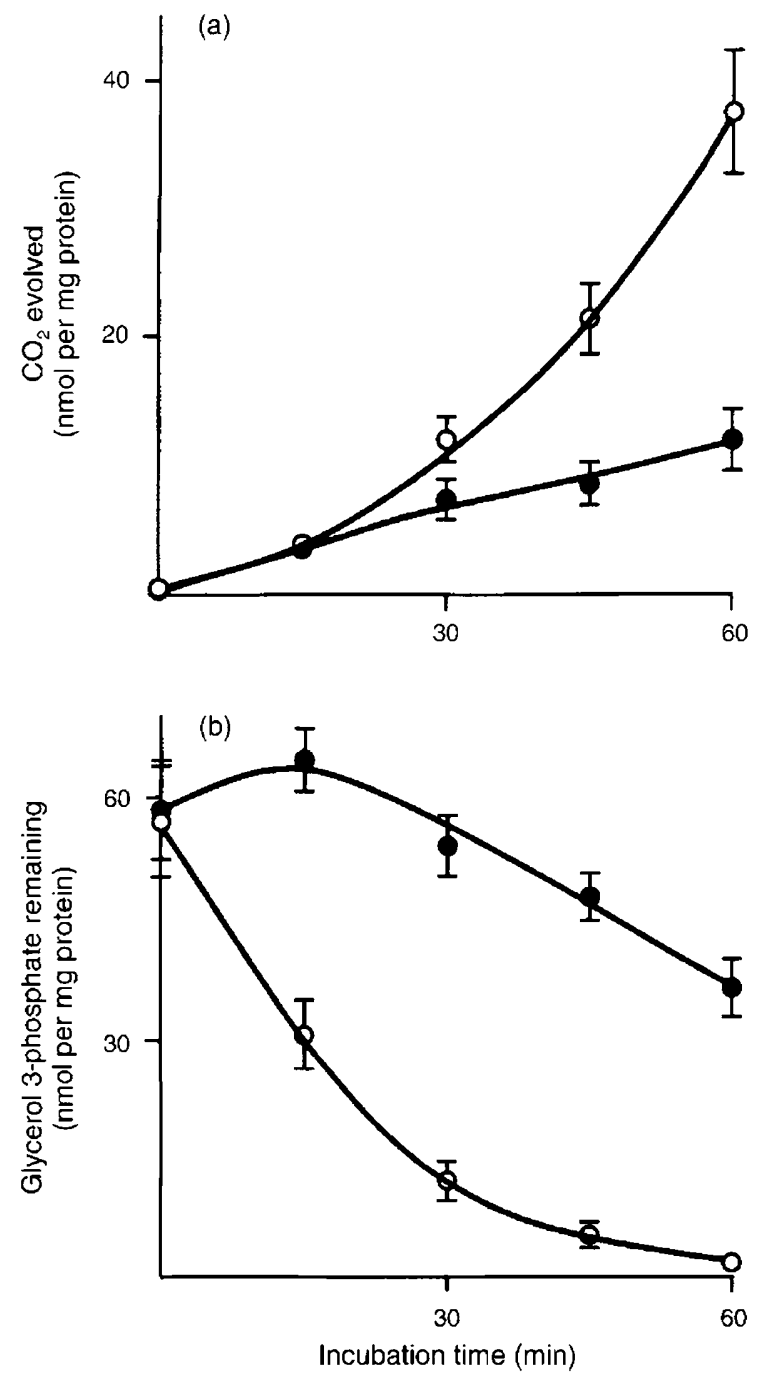

Fig. 2. Effect of $a$-bromohydrin phosphate on (a) the oxidation of glycerol 3-phosphate to $\mathrm{CO}_{2}(n=9)$ and (b) the consumption of glycerol 3-phosphate $(n=11)$ by boar spermatozoa. Spermatozoa were incubated at $34^{\circ} \mathrm{C}$ for $\mathrm{I} \mathrm{h}$ with glycerol 3-phosphate $(2 \mathrm{mmol}$ $\left.1^{-1}\right)$ in the presence $(0)$ or absence $(O)$ of $(R, S)-\alpha$-bromohydrin phosphate $\left(5 \mathrm{mmol} \mathrm{I}^{-1}\right)$.

suspensions, whereas over 90 nmoles of glycerol 3-phosphate were oxidized $\mathrm{min}^{-1} \mathrm{mg}^{-\mathrm{T}}$ protein over the same period (Fig. 4).
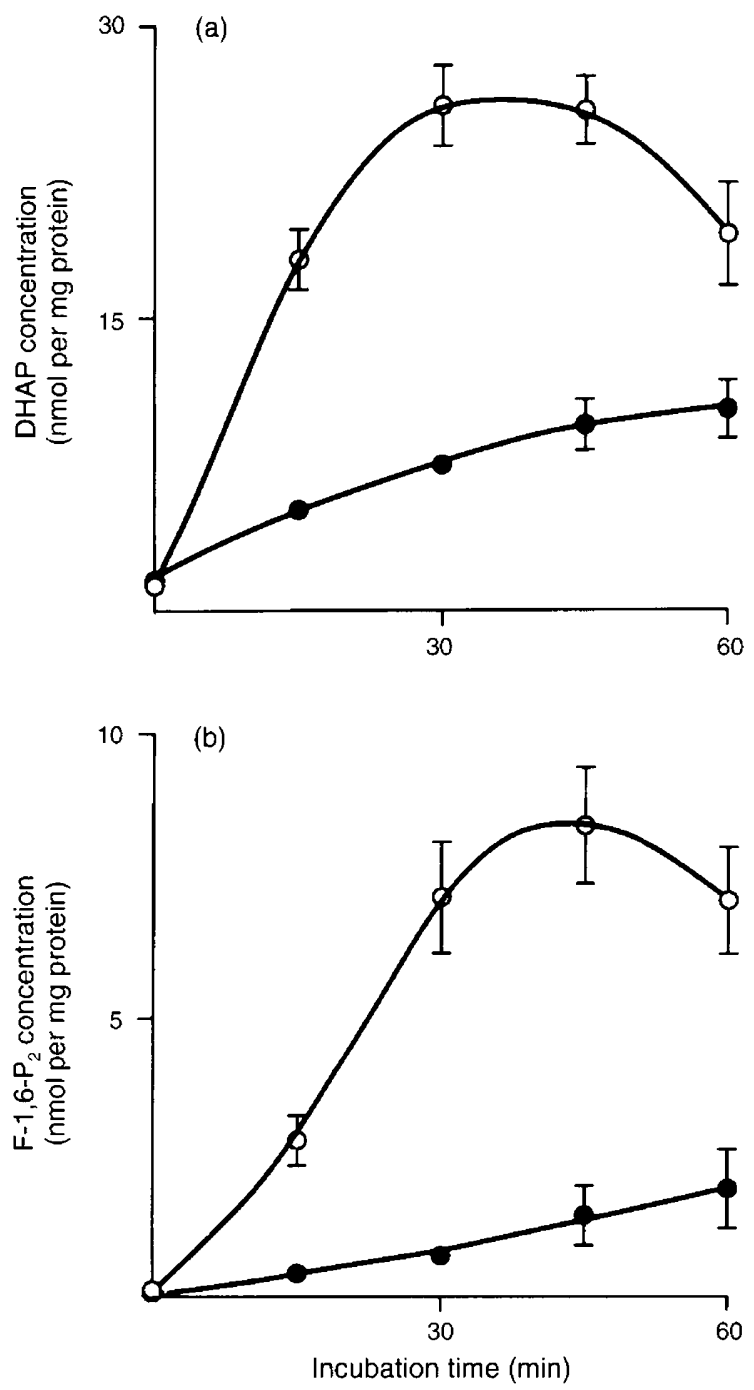

Fig. 3. Effect of $\alpha$-bromohydrin phosphate on the concentration of (a) dihydroxyacetone phosphate (DHAP) $(n=8)$ and (b) fructose-1,6bisphosphate $\left(\mathrm{F}-1,6-\mathrm{P}_{2}\right)(n=8)$ in boar spermatozoa. Spermatozoa were incubated at $34^{\circ} \mathrm{C}$ for $1 \mathrm{~h}$ with glycerol 3 -phosphate $(2 \mathrm{mmol}$ $\left.1^{-1}\right)$ in the presence $(0)$ or absence $(O)$ of $(R, S)$ - $a$-bromohydrin phosphate $\left(5 \mathrm{mmol} \mathrm{I}^{-1}\right)$.

The consumption of oxygen by sperm suspensions, determined as $0.67 \pm 0.20 \mathrm{nmol} \mathrm{min}{ }^{-1} \mathrm{mg}^{-1}$ protein $(n=5)$, was reduced to $0.17 \pm 0.05 \mathrm{nmol} \mathrm{min}{ }^{-1} \mathrm{mg}^{-1}$ protein $(n=6)$ in 


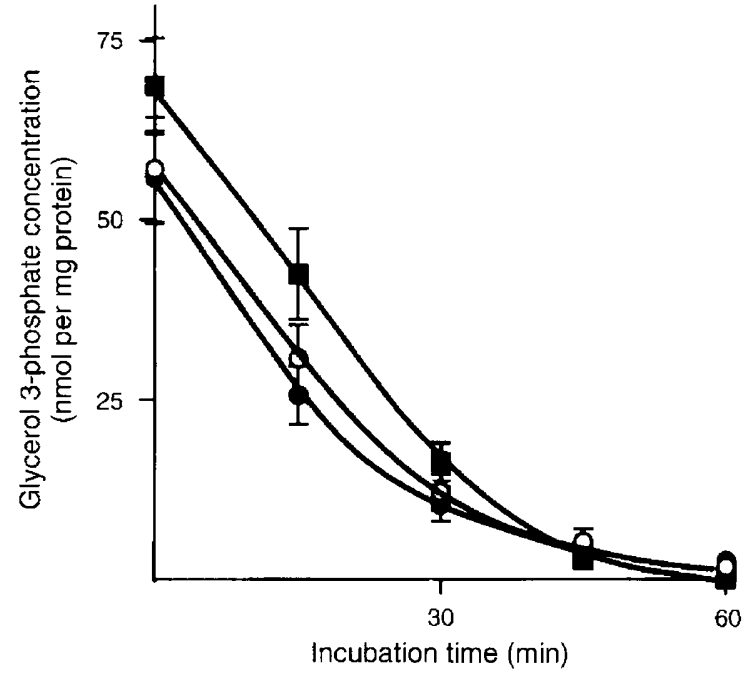

Fig. 4. Consumption of glycerol 3-phosphate by boar spermatozoa (O) $(n=15)$. Spermatozoa were incubated at $34^{\circ} \mathrm{C}$ for $1 \mathrm{~h}$ with glycerol 3-phosphate $\left(2 \mathrm{mmol} \mathrm{l}^{-1}\right)$ in the presence of ( $) 3$-chloro1-hydroxypropanone $\left(0.5 \mathrm{mmol} \mathrm{l}^{-1}\right)(n=14)$ or (目) 3-bromopyruvate $\left(0.5 \mathrm{mmol} \mathrm{l}^{-1}\right)(n=5)$.

the presence of 3-bromopyruvate, which inhibited the oxidation of endogenous substrates. With glycerol 3-phosphate as the substrate, the consumption of oxygen increased to $1.53 \pm 0.07 \mathrm{nmol} \min ^{-1} \mathrm{mg}^{-1}$ protein $(n=9)$; this was decreased to $1.23 \pm 0.09 \mathrm{nmol} \mathrm{min}{ }^{-1} \mathrm{mg}^{-1}$ protein $(n=6)$ on addition of 3-bromopyruvate and fell further to $0.59 \pm$ $0.16(n=4)$ on the addition of a-bromohydrin phosphate. Spermatozoa consumed more oxygen with glycerol 3-phosphate as the substrate than with either fructose or lactate, and rotenone $\left(700 \mu \mathrm{mol} \mathrm{I}{ }^{-1}\right)$ inhibited the uptake of oxygen from lactate but not from glycerol 3-phosphate (Fig. 6).

When sperm suspensions were incubated in the presence of $\alpha$-bromohydrin phosphate ( 5 and $10 \mathrm{mmol} \mathrm{I}^{-1}$ ), inhibition of the rate of disappearance of glycerol 3-phosphate was overcome as the concentration of substrate was increased.

\section{Discussion}

Inhibition by $\alpha$-bromohydrin phosphate of the oxidation to $\mathrm{CO}_{2}$ of glycerol 3-phosphate, but not that of fructose, glycerol or lactate, indicates that the action of the compound involves the conversion of glycerol 3-phosphate to dihydroxyacetone phosphate. Interference with this process would account for the decrease in the production of $\mathrm{CO}_{2}$ and dihydroxyacetone phosphate and in the consumption of glycerol 3-phosphate. Incubations performed with glycerol 3-phosphate as the substrate in the presence of either 3-chloro-1hydroxypropanone, which inhibits triosephosphate isomerase and glyceraldehyde 3-phosphate dehydrogenase (Jones and Cooney, 1987, Cooney and Jones, 1988), or 3-bromopyruvate, which inhibits glyceraldehyde 3-phosphate dehydrogenase and 3-phosphoglycerate kinase (Jones et al, 1995), also prevented the production of $\mathrm{CO}_{2}$, resulted in an increase in concentrations of dihydroxyacetone phosphate and fructose1,6-bisphosphate, but had no appreciable effect on the
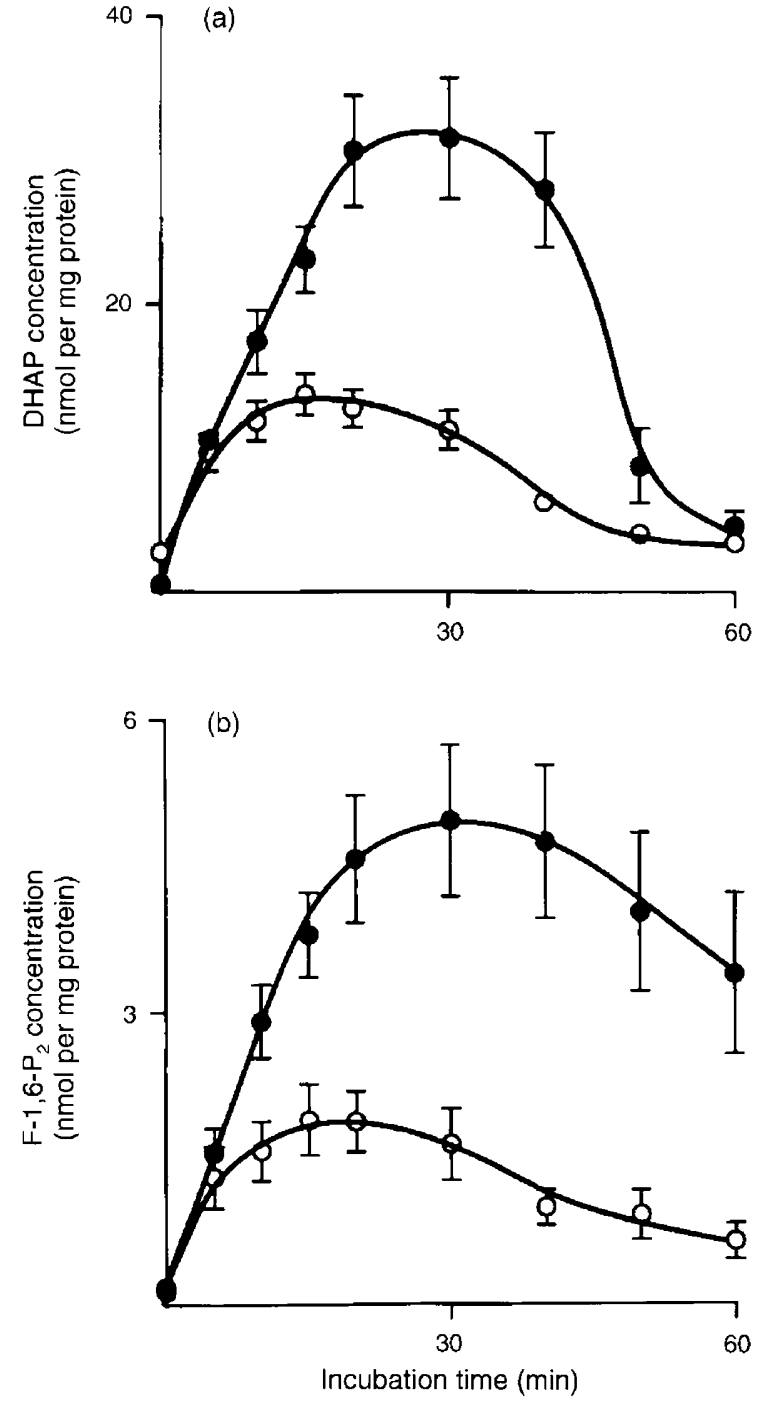

Fig. 5. Effect of 3-bromopyruvate on the concentration of (a) dihydroxyacetone phosphate (DHAP) $(n=6)$ and (b) fructose-1,6bisphosphate $\left(\mathrm{F}-1,6-\mathrm{P}_{2}\right)(n=6)$ in boar spermatozoa. Spermatozoa were incubated at $34^{\circ} \mathrm{C}$ for $1 \mathrm{~h}$ with glycerol 3 -phosphate $\{2 \mathrm{mmol}$ $\mathrm{I}^{-\mathrm{I}}$ ) in the presence $(0)$ or absence $(\mathrm{O})$ of 3-bromopyruvate $\left(0.5 \mathrm{mmol} \mathrm{l}^{-1}\right)$.

consumption of glycerol 3-phosphate. These results confirm that glycerol 3-phosphate was being oxidized to dihydroxyacetone phosphate and that $\alpha$-bromohydrin phosphate inhibited the rate of this oxidation.

Glycerol 3-phosphate can be oxidized to dihydroxyacetone phosphate by either an $\mathrm{NAD}^{+}$-dehydrogenase (EC 1.1.1.8) or an FAD-dependent (EC 1.1.99.5) glycerol 3-phosphate dehydrogenase (Voet and Voet, 1995); the former is located in the cytoplasm whereas the latter is bound to the inner mitochondrial membrane (Klingenberg and Bucholz, 1970). Examination of the activity of an $\mathrm{NAD}^{+}$-dependent glycerol 3-phosphate dehydrogenase in boar spermatozoa revealed that its activity was extremely low and, even when operating at the maximum activity that could be assayed, could not account for the rate of consumption of glycerol 3-phosphate. The consumption of oxygen when glycerol 3-phosphate was the 


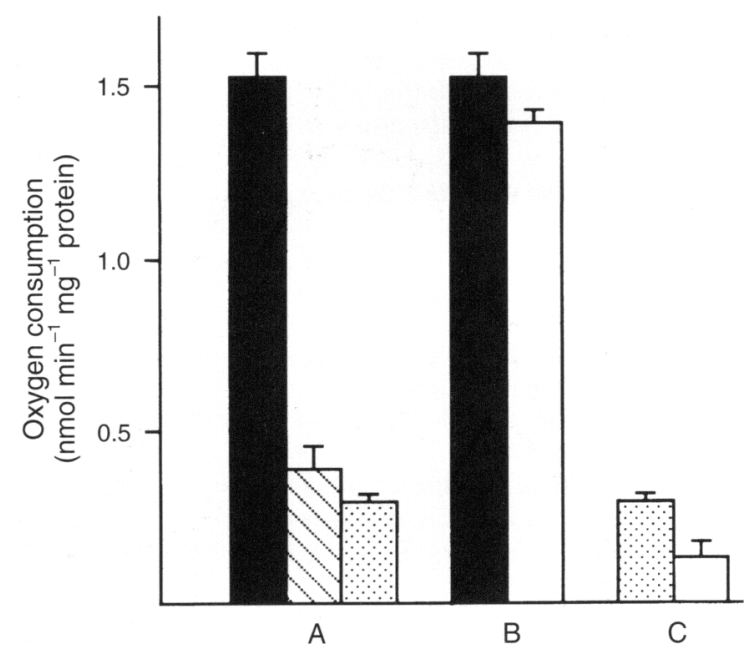

Fig. 6. Oxygen uptake by boar spermatozoa incubated with $(A)$ :

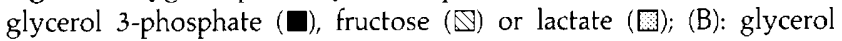
3-phosphate (D) and glycerol 3-phosphate plus rotenone ( $\square$ ) $(P<0.05)$ and $(C)$ : lactate (圆) and lactate plus rotenone ( $\square$ ) $(P<0.0001)$. Boar sperm suspensions were stirred at $34^{\circ} \mathrm{C}$ and the oxygen consumption measured for $10 \mathrm{~min}(n=4)$.

substrate was greater than when fructose or lactate were the substrates and this indicates that the oxidation of glycerol 3-phosphate is rapid, very dependent on the presence of oxygen and is inhibited by $\alpha$-bromohydrin phosphate.

The conversion of fructose or glucose to pyruvate produces ATP, by substrate-level phosphorylation, and NADH. It has been suggested that boar spermatozoa re-oxidize this $\mathrm{NADH}$ to $\mathrm{NAD}^{+}$to convert the pyruvate to lactate and that it is lactate which is the main metabolic fuel for mitochondrial metabolism (Jones and Chantrill, 1989). Thus, both fructose and lactate ultimately transfer cytoplasmic reducing equivalents to the mitochondria as NADH and these are processed by electron transport. An FAD-linked glycerol 3-phosphate dehydrogenase, however, would also transfer its reducing equivalents to the electron transport chain but at a position beyond that of NADH dehydrogenase. Inhibition of electron transport between the entry of $\mathrm{NADH}$ and $\mathrm{FADH}_{2}$ by rotenone showed little effect on the oxidation of glycerol 3-phosphate but had a marked effect on that of lactate.

These results confirm those of Ford (1981) that, in boar spermatozoa, glycerol 3-phosphate is oxidized primarily by an FAD-dependent dehydrogenase that is probably extrinsically bound to the inner mitochondrial membrane (Klingenberg and Buchoiz, 1970). In this respect, boar spermatozoa are similar to those of rams (Ford, 1981), rats (Ford, 1981; Brooks, 1978; Schenkman et al., 1965) and cocks (Yamada and Terada, 1974) but not those of mice (Burgos et al., 1982) or humans (Ford, 1981). The ability of $\alpha$-bromohydrin phosphate to inhibit this enzyme in boar spermatozoa is probably due to the $R$-isomer which has identical stereochemistry to the normal substrate (S)(or $s n$-) glycerol 3-phosphate. The manner of inhibition appears to be competitive since preliminary studies showed that increasing the concentration of substrate overcame the inhibitory action of a constant concentration of $\alpha$-bromohydrin phosphate.
Given that boar spermatozoa are efficient at metabolising glycerol 3-phosphate (Jones and Gillan, 1996), and that lactate, rather than pyruvate, is the major mitochondrial fuel (Jones and Chantrill, 1989), the presence of a membrane-bound glycerol 3-phosphate dehydrogenase makes it unnecessary to possess other shuttle mechanisms to transfer cytoplasmic reducing equivalents to the mitochondria. An FAD-linked glycerol 3-phosphate dehydrogenase acts, in effect, as the glycerol 3-phosphate shuttle while the entry of cytoplasmic lactate into the mitochondria performs a similar task by transferring cytoplasmic-derived reducing equivalents directly to the electron transport chain (Calvin and Tubbs, 1978; Gallina et al., 1994). Thus the metabolic activity of the cell would be most efficiently directed towards the mitochondrial production of ATP for cell motility.

This work was supported by the New South Wales Government Employees Medical Research Fund. We thank the employees of F. C. Nichols abattoir, Woy Woy, NSW for assistance in the collection of boar tissue and I. Darvey for helpful discussions on enzyme inhibition.

\section{References}

Banik UK, Tanikella T and Rakhit S (1972) Oral antifertility effects of halo propanediol derivatives in male rats Journal of Reproduction and Fertility 30 117-124

Brooks DE (1978) Activity and androgenic control of enzymes associated with the tricarboxylic acid cycle, lipid oxidation and mitochondrial shuttles in the epididymis and epididymal spermatozoa of the rat Biochemical Journal 174 $741-752$

Burgos C, Coronel CE, Gerez de Burgos NM, Rovai LE and Blanco A (1982) Studies in vitro on shuttle systems of mouse spermatozoa Biochemical Journal 208 413-417

Calvin J and Tubbs PK (1978) Mitochondrial transport processes and oxidation of NADH by hypotonically treated boar spermatozoa European Journal of Biochemistry 89 315-320

Cooney SJ and Jones A (1988) Inhibitory effects of (S)-3-chlorolactaldehyde on the metabolic activity of boar spermatozoa in vitro Journal of Reproduction and Fertility $82 \quad 309-317$

Fondy TP, Ghangas GS and Reza MJ (1970) Synthesis of 1-haloanalogs of D,L-glycerol-3-phosphate and their effects on glycerol-3-phosphate dehydrogenase Biochemistry 9 3272-3280

Ford WCL (1981) The oxidation of glycerol 3-phosphate by testicular and epididymal spermatozoa Comparative Biochemistry and Physiology 68B 289-293

Gallina FG, Gerez de Burgos NM, Burgos C, Coronel CE and Blanco A (1994) The lactate/pyruvate shuttle in spermatozoa: operation in vitro Archives of Biochemistry and Biophysics 308 515-519

Holtz W and Smidt D (1976) The fertilizing capacity of epididymal spermatozoa in the pig Journal of Reproduction and Fertility 46 227-229

Jones AR and Chantrill LA (1989) Oxidative metabolic activity of boar spermatozoa: a system for assessing anti-glycolytic activity of potential inhibitors in vitro Reproduction, Fertility and Development 1357-367

Jones AR and Cooney SJ (1987) Inhibition of triosephosphate isomerase in boar spermatozoa by (S)-3-chlorolactaldehyde Biochemical and Biophysical Research Communications 145 1054-1058

Jones AR and Gillan L (1996) Metabolism of glycerol 3-phosphate by mature boar spermatozoa Journal of Reproduction and Fertility 106 321-327

Jones AR and Porter LM (1995) Inhibition of glycolysis in boar spermatozoa by $a$-chlorohydrin phosphate may be mediated by phosphatase activity Reproduction, Fertility and Development 7 1089-1094

Jones AR, Chantrill LA and Cokinakis A (1992) Metabolism of glycerol by mature boar spermatozoa Journat of Reproduction and Fertility 94 129-134

Jones AR, Gillan L and Milmlow D (1995) The anti-glycolytic activity of 3-bromopyruvate on mature boar spermatozoa Contraception $\mathbf{5 2}$ $317-320$ 
Jones AR, Bubb WA, Murdoch SR and Stevenson DA (1986) Inhibition of fructolytic enzymes in boar spermatozoa by $(S)-\alpha$-chlorohydrin and 1-chloro-3-hydroxypropanone Australian Journal of Biological Sciences 39 395-406

Klingenberg M and Bucholz M (1970) Localization of the glycerol-phosphate dehydrogenase in the outer phase of the mitochondrial inner membrane European Journal of Biochemistry 13 247-252

Lang G (1985) L-(-)-Glycerol 3-phosphate. In Methods of Enzymatic Analysis (3rd Edn) Vol. VI pp 525-530 Ed. HU Bergmeyer. Verlag Chemie, Weinheim

Lowry OH, Roseborough NJ, Farr AL and Randall RJ (1951) Protein measurement with the Folin phenol reagent Journal of Biological Chemistry 193 265-275

Mashford PM and Jones AR (1978) The antifertility action of $\alpha$-chlorohydrin: enzyme inhibition by a-chlorohydrin phosphate Experientia 34 1267-1268

Michal G and Beutler H-O (1975) D-Fructose-1,6-diphosphate, dihydroxyacetone phosphate and 0-glyceraldehyde-3-phosphate. In Methods of Enzymatic Analysis Vol. 3 pp 1314-1319 Ed. HU Bergmeyer. Academic Press, New York

Mohri H, Suter DAI, Brown-Woodman PDC, White IG and Ridley DD (1975) Identification of the biochemical lesion produced by $a$-chlorohydrin in spermatozoa Nature 255 75-77
Porter LM and Jones AR (1995) Inhibition of glyceraldehyde 3-phosphate dehydrogenase in boar spermatozoa by bromohydroxypropanone Reproduction, Fertility and Development 7 107-111

Schenkman JB, Richert DA and Westerfeld WW (1965) $\alpha$-Glycerophosphate dehydrogenase activity in rat spermatozoa Endocrinology 76 1055-1061

Sprinson DB and Chargaff E (1946) $\beta$-Hydroxy- $\alpha$-keto acids Journal of Biological Chemistry 164 417-4.32

Stevenson $D$ and Jones AR (1982) Inhibition of fructolysis in boar spermatozoa by the male antifertility agent (S)- $\alpha$-chlorohydrin Australian Journal of Biological Sciences 35 595-605

Stevenson D and Jones AR (1985) Production of (S)-3-chlorolactaldehyde from (S)- $\alpha$-chlorohydrin by boar spermatozoa and the inhibition of glyceraldehyde 3-phosphate dehydrogenase in vitro Journal of Reproduction and Fertility 74 157-165

Umbreit WW, Burris RH and Stauffer Jf (1957) Manometric Techniques (3rd Edn) pp 1-17. Burgess Publishing Co., Minneapolis

Voet D and Voet JG (1995) Biochemistry (2nd Edn) pp 567 and 666. Wiley, New York

Yamada M and Terada T (1974) L- $\alpha$-Glycerol 3-phosphate as an oxidative substrate for cock spermatozoa American Journal of Physiology 227 729-733 